\title{
Nitrate content in vegetables and fruits in Russia and Mongolia
}

\author{
Yulia Smyatskay ${ }^{1, *}$, Ilona Pankina $^{1}$, Larisa Kulikova $^{2}$, and Daria Sobgaida ${ }^{2}$ \\ ${ }^{1}$ Peter the Great Sankt-Petersburg Polytechnic university \\ ${ }^{2}$ Saratov State Medical University
}

\begin{abstract}
This article deals with the actual problem of high nitrate content in vegetables and fruits. The literature review describes the consequences of increased nitrate concentration in the human body and the diseases associated with it. Different countries have different standards for the content of nitrates in agricultural products and the maximum permissible daily doses. The increased content of nitrates negatively affects human health, so it is necessary to maintain strict control over compliance with the concentration standards to the maximum permissible concentrations. Research was carried out on the content of nitrates in vegetables and fruits purchased in the trade networks of the two countries in Russia and Mongolia. The measurements were performed using a portable nitrate - tester SOEKS. As a result of the study, it was found that agricultural products purchased in the trade network of Ulan Bator (Mongolia) meet the established standards, in fruits purchased in St. Petersburg (Russia) in excess of tangerines 1.5 times and 1.6 times. The products that were found to contain excess nitrates were imported from China.
\end{abstract}

\section{Introduction}

The problem of eating quality food is relevant for residents of different countries. A significant part of the diet of adults and children are vegetables and fruits. High-quality agricultural products are the key to human health.

One of the main indicators of the quality of vegetables and fruits is the content of nitrates. Nitrogen is the main element involved in all biological processes.

Fertilizers based on nitric acid salts are widely used for soil fertilization [1]. Adding nitric acid salts to the soil allows you to reduce the time of maturation of the crop, increase the number of crops and get the fruits of the marketable type. Irrational use of fertilizers and noncompliance with the rules of their use leads to the accumulation of nitrates in plants [2]. Getting high levels of nitrates in the human body with consumed vegetables and fruits entails serious problems.

In the gastrointestinal tract, nitrates under the action of microorganisms are reduced to nitrites, which cause problems in the form of nitrate-nitrite methemoglobinemia. This disease-cyanosis, is manifested by an increase in the content of methemoglobin in the blood and a decrease in blood pressure. All this leads to a violation of metabolism, the activity of the nervous system, reducing the overall resistance of the body. The concentration of methemoglobin about $15 \%$ causes lethargy, drowsiness. Signs of poisoning - nausea, vomiting, diarrhea, low blood pressure-appear within 1-6 hours. At the same time, there is an uneven, weak pulse, cyanosis of the skin, cold limbs, rapid breathing, headache, tinnitus, facial muscle spasms, impaired coordination of movements, loss of consciousness and coma may occur [3-4]. Although acute nitrate poisoning is deadly, it is not as common as chronic nitrate methemoglobinemia. Its development is facilitated by the systematic consumption of food products that contain significant amounts of nitrates and nitrites. If nitrates enter the body for a long period of time, it can even lead to anemic anoxia. Very significant is the fact that methemoglobin is formed in the absence of cyanosis.

It is dangerous to get nitrates and nitrites into the body of pregnant women during the formation of the fetus. When cooking, the content of nitrates in products can be reduced or increased. The reduction is due to the cleaning and removal of the most nitrate parts of plants. In addition, when washing and soaking part of the nitrates goes into the water. There is an equalization of nitrate concentrations in water and products. The content of nitrates in vegetables will be less, the more water there is, the longer the soaking and the less nitrates in the water.

For an adult, the maximum permissible rate of nitrates is $5 \mathrm{mg}$ per $1 \mathrm{~kg}$ of human body weight, and nitrites- $0.2 \mathrm{mg}$ per $1 \mathrm{~kg}$. For a child, the permissible rate is no more than $50 \mathrm{mg}$. A person can relatively easily tolerate a dose of $150-200 \mathrm{mg}$ of nitrates per day, 500 mg-the maximum permissible dose, $600 \mathrm{mg}$-toxic for adults. $10 \mathrm{mg}$ of nitrates is enough to poison a baby. In the diet of people, the daily dose of nitrates, including the one that comes with drinking water, should not exceed $300-325 \mathrm{mg}$, for apples it is $60 \mathrm{mg} / \mathrm{kg}$ of raw weight.

The high content of nitrates noted in the drought period, when the temperature of soil and air environment, with a decrease in soil molybdenum,

\footnotetext{
* Corresponding author: Makarovayulia169@mail.ru
} 
cobalt, sulfur and potassium, with high acidity, soil salinity and soil large quantities of organic fertilizers (liquid manure, chicken manure) [5-6].

Leafy vegetables and some root vegetables - salads, young cabbage, greens, beet tops, radishes, beets-are characterized by a high content of nitrates. Mediumcucumbers, young carrots, late cabbage, green onions. Low - tomatoes, peas, capsicum, garlic, potatoes, carrots. In leafy vegetables, nitrates accumulate mainly in the stems, root system, and veins. Therefore, it is better to use greens without stems, and remove the cabbage stalk. In carrots, most of the nitrates accumulate in the core, in cucumbers and radishes-in the skin, in zucchini and eggplant-in the stalk area, in beets - on both sides [7].

The problem of high nitrate content in vegetables, fruits, meat, and dairy products is relevant for scientists in different countries [8-11].

The standards of nitrate content in food also differ for different countries, for example, in the European Union, the norms of nitrate content in vegetable products are regulated by the regulation EK Nr.1258/2011. According to this document, the maximum allowable amount of nitrates in spinach is $3500 \mathrm{mg} / \mathrm{kg}$, in head and leaf lettuce in the summer (from April 1 to September 30 inclusive) $4000 \mathrm{mg} / \mathrm{kg}$ in protected soil products and $3000 \mathrm{mg} / \mathrm{kg}$ in open ground products, in crunchy salad (iceberg type) $2500 \mathrm{mg} / \mathrm{kg}$ in protected soil products and $2000 \mathrm{mg} / \mathrm{kg}$ in open ground products, in arugula in the summer $6000 \mathrm{mg} / \mathrm{kg}$ and in baby food $200 \mathrm{mg} / \mathrm{kg}$.

Neither cucumbers, nor tomatoes, nor green onions, watermelons, melons and other vegetables and melons contain nitrates in the European Union is not limited. Nitrates in vegetables are limited only in the Russian Federation, Ukraine and Belarus [12]

The maximum permissible concentration (MPC) of nitrates in vegetable products in various countries of the world varies significantly. The Russian Federation has the lowest MPC in comparison with foreign countries. For example, the MPC of nitrates for table beet in the Czech Republic is $3500 \mathrm{mg}$, in Austria, $3500 \mathrm{mg}$, in USA - $3600 \mathrm{mg}$ in Holland - $4000 \mathrm{mg}$ at a rate of RF $1400 \mathrm{mg}$ per $1 \mathrm{~kg}$ wet weight.

\section{Materials and methods}

Vegetables and fruits consumed by the residents of Russia and Mongolia and purchased in the retail chain of Ulan Bator and St. Petersburg were selected as the object of the study. The products were purchased by a local manufacturer and brought from other countries, particularly China and Ecuador.

In the city of Ulan Bator, the following agricultural products were studied: bananas, potatoes, tomatoes, carrots, and apples.

In Russia, the following test objects were selected: sweet pepper, cucumber, banana, mandarin, potatoes, persimmon, lemon. Nitrate levels were measured using the SOEKS nitrate tester (Russia). Nitrat-tester SOEKS is designed for express analysis of fresh fruit, vegetables for nitrates. Nitrat content analysis is based on conductivity of alternating high-frequency current the measured food items.

Measurements were made at a temperature of $250 \mathrm{C}$.

Measurement mistake, less $30 \%$. Range of indicated nitrate content from 20 to $5000 \mathrm{mg} / \mathrm{kg}$.

The measurements were performed in 3 dimensions followed by statistical processing of the results.

\section{Results and Discussion}

The results of measurements of nitrates in vegetables and fruits purchased in the retail network of Ulan Bator (Mongolia) are presented in table 1 .

Table 1. The composition of the environment for the cultivation of activated sludge.

\begin{tabular}{|c|c|c|c|}
\hline $\begin{array}{c}\text { Title } \\
\text { agricultural } \\
\text { products }\end{array}$ & $\begin{array}{c}\text { Country } \\
\text { importer / } \\
\text { manufacturer }\end{array}$ & $\begin{array}{c}\text { Measured } \\
\text { value, } \\
\mathbf{m g} / \mathbf{k g}\end{array}$ & $\begin{array}{c}\text { Stand- } \\
\text { art }^{*}\end{array}$ \\
\hline Banana & Ecuador & $130 \pm 39$ & 200 \\
\hline $\begin{array}{c}\text { Potatoes (in the } \\
\text { middle) }\end{array}$ & Mongolia & $100 \pm 30$ & 250 \\
\hline $\begin{array}{c}\text { Potatoes (under } \\
\text { the skin) }\end{array}$ & Mongolia & $177 \pm 53$ & 250 \\
\hline Tomato & Mongolia & $203 \pm 61$ & 300 \\
\hline Apple & Russia & $48 \pm 14$ & 60 \\
\hline Carrots (core) & Mongolia & $179 \pm 54$ & 250 \\
\hline $\begin{array}{c}\text { Carrots } \\
\text { (lower part) }\end{array}$ & Mongolia & $154 \pm 46$ & 250 \\
\hline *-Russian standard 2.3.2.1078-01 \\
\hline \multicolumn{3}{|l}{} \\
\hline \multicolumn{4}{|l}{} \\
\hline
\end{tabular}

Vegetables for research were taken by domestic producers (potatoes, carrots, apples), and bananas brought from other countries (Ecuador).

Studies have shown that all vegetables and fruits contain nitrates that meet the standard. In carrots, nitrate concentrations were measured in different parts of the plant, in the core and in the lower part. The concentration of nitrates in the core was higher than in the lower part of the carrot, which indicates an uneven distribution of nitrates in different parts of the root crop.

Nitrate levels in potatoes were also measured under the skin and closer to the core. The concentration of nitrates was higher under the skin of the vegetable, which also confirms the literary research.

The next object of research was vegetables and fruits purchased in the retail chain of St. Petersburg (Russia). The measurement results are presented in table 2 .

The nitrate concentration in potatoes was measured after pre-soaking in clean tap water for 12 hours and without pretreatment. Pre-soaking reduced the nitrate content by $5 \%$. 
Table 2. Results of measurements of the level of nitrates in products purchased in St. Petersburg (Russia).

\begin{tabular}{|c|c|c|c|}
\hline $\begin{array}{c}\text { Title } \\
\text { agricultural } \\
\text { products }\end{array}$ & $\begin{array}{c}\text { Country } \\
\text { importer / } \\
\text { manufactur } \\
\text { er } \\
\end{array}$ & $\begin{array}{l}\text { Measured } \\
\text { value, } \\
\text { mg/kg }\end{array}$ & $\begin{array}{c}\text { Stand- } \\
\text { art }^{*}\end{array}$ \\
\hline Banana & Ecuador & $157 \pm 47$ & 200 \\
\hline $\begin{array}{c}\text { Potatoes } \\
\text { (pre-soaked in } \\
\text { water for } 12 \\
\text { hours) }\end{array}$ & Russia & $137 \pm 41$ & 250 \\
\hline $\begin{array}{c}\text { Potatoes } \\
\text { without } \\
\text { processing } \\
\end{array}$ & Russia & $143 \pm 43$ & 250 \\
\hline Tomato & Russia & $179 \pm 54$ & 300 \\
\hline $\begin{array}{l}\text { Cucumber } \\
\text { greenhouse } \\
\text { (core) }\end{array}$ & Russia & $230 \pm 69$ & 400 \\
\hline $\begin{array}{l}\text { Cucumber } \\
\text { greenhouse } \\
\text { (bottom) }\end{array}$ & Russia & $202 \pm 61$ & 400 \\
\hline Carrots (core) & Russia & $177 \pm 53$ & 250 \\
\hline $\begin{array}{c}\text { Carrot } \\
\text { (bottom) }\end{array}$ & Russia & $158 \pm 47$ & 250 \\
\hline Sweet papper & Israel & $54 \pm 16$ & 200 \\
\hline Apple & Russia & $84 \pm 25$ & 60 \\
\hline Limon & China & $73 \pm 22$ & 60 \\
\hline Pear & China & $46 \pm 14$ & 60 \\
\hline Tangerine & China & $88 \pm 26$ & 60 \\
\hline Persimmon & China & $95 \pm 29$ & 60 \\
\hline
\end{tabular}

Measurements of nitrates in cucumber greenhouse production Russia indicate an uneven distribution of nitrates in the vegetable, as well as in carrots, in the core of the accumulation of nitrates is higher than in other parts of the plant.

The measurement of the nitrate content in lemons and apples revealed an excess within the margin of error. In tangerines and persimmons imported from China, the excess of nitrates was found in 1.5 and 1.6 times.

The assessment of nitrate content in agricultural products in both countries was carried out in the winter, respectively, the decrease in the concentration of nitrates in vegetables that are subject to storage occurred naturally. It is known that as a result of storage, the concentration of nitrates decreases [13]. For storage, as a rule, late varieties are chosen, which also contain less nitrates.

\section{Conclusions}

The research of vegetables and fruits purchased in the trade networks of Ulan Bator and St. Petersburg was carried out.

Products purchased in the trade network of Ulan Bator fully comply with the standards of nitrate content in agricultural products.

Products purchased in the retail chain of St. Petersburg.

\section{References}

[1] V.V. Epifantsev, S.V. Stokoz, T.V. Zakharov, Far Eastern agrarian Bulletin, 1, 45 (2018).

[2] S.I. Krokhaleva, Studied in Russia [Electronic resource]. Available at: http/zhurnal.ape.relarn.ru/articles/2004/061.pdf.

[3] T.A. Erdyneeva, Bulletin of Tuvan state University, Natural and agricultural Sciences, 2, 37 (2018).

[4] About nitrates, Danger behind nitrates, Symptoms of acute poisoning by nitrates [Electronic resource]. Available at: http://www.dosimeter4you.com/nitrates.php.

[5] N.P. Ocheret, F.V. Tuguz, Bulletin of AGU, 2, 221 (2018).

[6] S. Gilda, Juan E. Álvaro, M. Urrestarazu, Effect of the organic production system and seasonality on nitrate content in vegetables from Spanish supermarkets. Sylwan, 160, 348-363 (2016).

[7] I.P. Saldan, Health risk analysis, 4 (2018).

[8] G. Orymbetova, G. Shambulova, E. Orymbetov, M. Kasymova, Z. Kobzhasarova, Assessment of nitrates content in vegetables grown in South Kazakhstan Region (Shymkent city), Food Processing: Techniques and Technology, 48, 150-155 (2018). DOI: 10.21603/2074-94142018-1-150-155.

[9] N. Razgallah, H. Chikh Rouhou, I. Boughattas, M. Hamdi, Nitrate contents in some vegetables in Tunisia, Archives of Agronomy and Soil Science, 62 (2015). DOI: 150714083947009. 0.1080/ 03650340.2015.1072623.

[10] F. Corradini, A. Correa, S. Moyano, P. Sepúlveda, C. Quiroz, Nitrate, arsenic, cadmium, and lead concentrations in leafy vegetables: expected average values for productive regions of Chile, Archives of Agronomy and Soil Science, 64 2017). DOI: 10.1080/03650340.2017.1346790.

[11] Ze-Yi Zhou, Wang, Ming-Jian, Ju-Si. Wang, Nitrate and nitrite contamination in vegetables in China, Food Rev. Int., 16, 1, 61-76 (2007). DOI: 10.1081/FRI-100100282.

[12] Electronic resource. Available at: https://www.facebook.com/notes/mārītegailīte/o-nitratah-i-ovocshah-321540697922 $347 /$.

[13] S.A. Witchenko, G.D. Ledovskaya, Young scientist, 1, 76-80 (2017). 